\title{
CBCT Evaluation of the Mandibular Bone Quality in Relation to Skeletal Status After Treatment with Strontium Renelate in Diabetic Patients
}

\author{
ALEXANDRU NEMTOI ${ }^{1}$, ANA NEMTOI ${ }^{2}$, ALEXANDRA FOCHI ${ }^{2}$, ANA ELENA SIRGHE², CRISTINA PREDA ${ }^{3}$, KAMEL EARAR ${ }^{4 *}$, \\ ADRIAN BEZNEA4, CRISTIAN ONISOR ${ }^{4 *}$, GABRIELA IORGULESCU5, DANISIA HABA ${ }^{2}$ \\ ${ }^{1}$ Grigore T. Popa University of Medicine and Pharmacy, Department of Morpho-Functional Sciences, 16 Universitatii Str., 700115 , \\ lasi, Romania \\ ${ }^{2}$ Grigore T. Popa University of Medicine and Pharmacy, Department of Oral and Maxillofacial Surgey, 16 Universitatii Str., 700115, \\ lasi, Romania \\ ${ }^{3}$ Grigore T. Popa University of Medicine and Pharmacy, Department of Endocrinology, 16 Universitatii Str., 700115, Iasi, Romania \\ ${ }^{4}$ Dunarea de Jos University of Medicine and Pharmacy Faculty, Department of Dentistry,47 Domneasca Str.800008, Galati, \\ Romania \\ ${ }^{5}$ University of Medicine and Pharmacy Carol Davila, Dental Medicine Faculty, 19 Calea Plevnei, 010221, Bucharest, Romania
}

The aim of this study was to evaluate the diagnostic efficacy of the cone beam computed tomography (CBCT) - based mandibular indices and the CBCT mandibular bone density values and to determine whether they correlate with bone mineral density (BMD) of the lumbar spine $\left(L_{1}-L_{4}\right)$ and proximal left femur in patients with osteoporosis and diabetes mellitus, which were taken a treatment with strontium ranelate over a period of 6 months. The study included 20 osteoporosis patients and 40 diabetic patients (16 patients - type 1 diabetes mellitus and 24 patients - type 2 diabetes mellitus). In CBCT images, the radiomorphometric indices were measured in the right and left mandibles. The relationship between the CBCT measurements of the mandible and skeletal BMD was assessed. The present study showed that mandibular bone quality is closely correlated with the skeletal status of the patients with osteoporosis and diabetes mellitus which were in treatment with strontium ranelate for bone improving.

Keywords: cone beam computed tomography; dual energy X-ray absorptiometry; mandible; diabetes mellitus, osteoporosis; strontium ranelate

Ageing accompanied by various diseases represents one major problem of our century, causing a need to study the factors that help to prevent this. One of these problems is the diabetes mellitus which is a metabolic pandemic disease accompanied by substantial morbidity and mortality.

Patients with diabetes mellitus present various skeletal disorders such as osteopenia, osteoporosis, increased fracture risk, poor osseous healing characteristics and impaired bone regeneration potential [ 1 - 4]. The mineral composition of bone in patients affected by diabetes can be mainly due to direct effects of insulin deficiency and high blood sugar concentration on bone tissue $[5,6]$.

Osteoporosis is one of the most important metabolic bone disorders in patients with diabetes mellitus causing a reduction in the bone mineral density [7]. There are still controversies about the values of bone mineral density and the risk of osteoporosis in patients with diabetes mellitus. Most studies have reported low bone mineral density in patients with type 1 diabetes mellitus [ 8 - 11]. On the other hand, studies have demonstrated the presence of lower values, [12] similar [13] or greater [14] in patients with type 2 diabetes mellitus.

In oral implantology, healthy bones with a normal regenerative capacity are essential for a successful outcome. The jaws may be affected by various drugs or systemic disease in terms of bone quality [15-18].

In the last decade, certain studies have showed a relationship between changes that may occur in the mandibular bone and skeletal BMD status [19]. One of the earliest suggestions for a link between osteoporosis and jaw bone resorption was observed since 1968 [20].

Some authors have argued that there is a strong relationship between mandibular cortical thickness and systemic osteoporosis [21].
Itwould be very useful to be able to identify the changes that occur in the mandible imaging investigation and we can guide a systemic evaluation and diagnosis of osteopenia or osteoporosis. Clinicians have pointed out that the imaging investigations allow to calculate the radiomorphometric indices and jaw bone density, which can be a criterion for the diagnosis of osteoporosis and to correlate to skeletal BMD [22].

These radiomorphometric indices where represented by: superior and inferior mandibular index, mental index and mandibular cortical index were analyzed on panoramic radiographs [23-25]. There are few studies that have used these indices on the CBCT images to evaluate the mandibular bone quality [26]. Until now, no studies have been conducted to compare the quality of the mandibular bone and the skeletal status in patients with diabetes mellitus.

The aim of this study was to evaluate the diagnostic efficacy of the CBCT - based mandibular indices and the CBCT mandibular bone density values and to determine whether they correlate with bone mineral density (BMD) of the lumbar spine (L1 - L4) and proximal left femur in patients with osteoporosis and diabetes mellitus which were taken a treatment with strontium ranelate over a period of 6 months.

\section{Experimental part \\ Participant selection}

The study was conducted in the Department of Oral and Maxillofacial Radiology, Gr. T. Popa University of Medicine and Pharmacy lasi, Romania. The study was approved by the Ethics Committee of our University.

The study included 20 osteoporotic patients and 40 diabetic patients ( 16 patients -type 1 diabetes mellitus and 24 patients -type 2 diabetes mellitus), which were taken a treatment with strontium ranelate $2 \mathrm{~g}$ per day, over a period 
of 6 months. All of the diabetic patients were diagnosed before strating to take strontium ranelate with an osteoporotic status in differenrt regions of the skeleton system. Patients included in this study were selected from the Clinic of Diabetes, Nutrition and Metabolic Diseases, Emergency Hospital St. Spiridon, Iasi, Romania.

The inclusion criteria for the osteoporotic group were: men aged between 20 and 55 and different classes of mandible edentulous and other secondary causes of osteoporosis. Exclusion criteria were: diabetes mellitus and local conditions impacting the mandible.

The inclusion criteria for the diabetic group were: men aged between 20 and 55, suffering from diabetes and different classes of mandible edentulous. Exclusion criteria were: local conditions impacting the mandible and other secondary causes of osteoporosis except diabetes mellitus: endocrine, gastrointestinal disease, rheumatologic conditions, using various medications. Patients had signed informed consentbefore their inclusion in the study.

\section{Evaluation of bone mineral density at the lumbar spine and} proximal left femur

Bone mineral content (grams) and BMD (grams per centimeter squared) were measured with dual-energy $X$ ray absorptiometry using Hologic Delphi W densitometer DEXA scan (Dual Energy X-ray AbsoptiometryS / N 70490).

Regions of interest were proximal left femur and lumbar spine $\left(L_{1}-L_{A}\right)$. Proximal left femur and lumbar spine BMD was also expressed as a Z score and T score. The Z score is a standard deviation (SD) from the weight-adjusted average BMD for each age. A patient's BMD was given as a $\mathrm{T}$ - score, which is derived by comparing it to an average score for a healthy 30 year old of the same sex and race. The difference between the normal young score and the patient's scire is reffered to as a SD. Using DEXA scan, osteoporosis was defined by aT score of $\leq-2.5$, osteopenia as $T$ score between 1 and 2.5, and normal BMD T score $>-1$.

\section{CBCT examination of the mandible}

The equipment used was Planmeca Promax 3D Mid CBCT (Planmeca OY, Helsinki, Finland). Scanning was performed by selecting a field of view of $40 \times 40 \mathrm{~mm}$ and following exposure parameters: $90 \mathrm{kV}, 12 \mathrm{~mA}, 13.8$ seconds and $0.4 \times 0,4 \times 0,4 \mathrm{~mm}$ voxel size. Initial and final reconstructions were performed by software Romexis 3.0.1 (Planmeca OY, Helsinki, Finland). To achieve sagittal sections and panoramic CBCT reconstructions were established with a thickness of $1 \mathrm{~mm}$ and at a distance of $1 \mathrm{~mm}$.

\section{CBCT measurements}

The radiomorphometric indices, according to the classification of Ledgerton on panoramic images, which have been adapted on CBCT images were used in the present study.

The following indices were measured on CBCT images:

- CBCTI (S): cone beam computed tomography mandibular index (superior), which represents the ratio of the inferior cortical width to the distance from the superior margin of the mental foramen chin to the inferior border of the mandible (fig.1).

-CBCTI (I): cone beam computed tomography mandibular index (inferior), which represents the ratio of the inferior cortical width to the distance from the inferior margin of the mental foramen chin to the inferior border of the mandible (fig.1).

-CBCTMI: cone beam computed tomography mental index, which represents the inferior cortical width of the mandible (fig.1).

-CBCTCMI: cone beam computed tomography mandibular cortical index, which represents the type of the inferior mandibular cortical bone. The types of the of the inferior mandibular cortical bone were classified as follows:

Type 1: the cortical endosteal margin appears even and regular (fig. 2.A)

Type 2: the endosteal margin shows semilunar defects or 1 to 2 layers of cortical endosteal residues (fig.2.B)

Type 3: the cortical layer has numerous ( $>3$ ) endosteal residues and is clearly porous (fig.2.C)

In addition, we calculated the bone mineral density for cortical and cancellous bone of the mandible for each region of the interest. These measurements were performed on panoramic and sagittal reconstructions resulting from CBCT examination (fig.3). All measurements
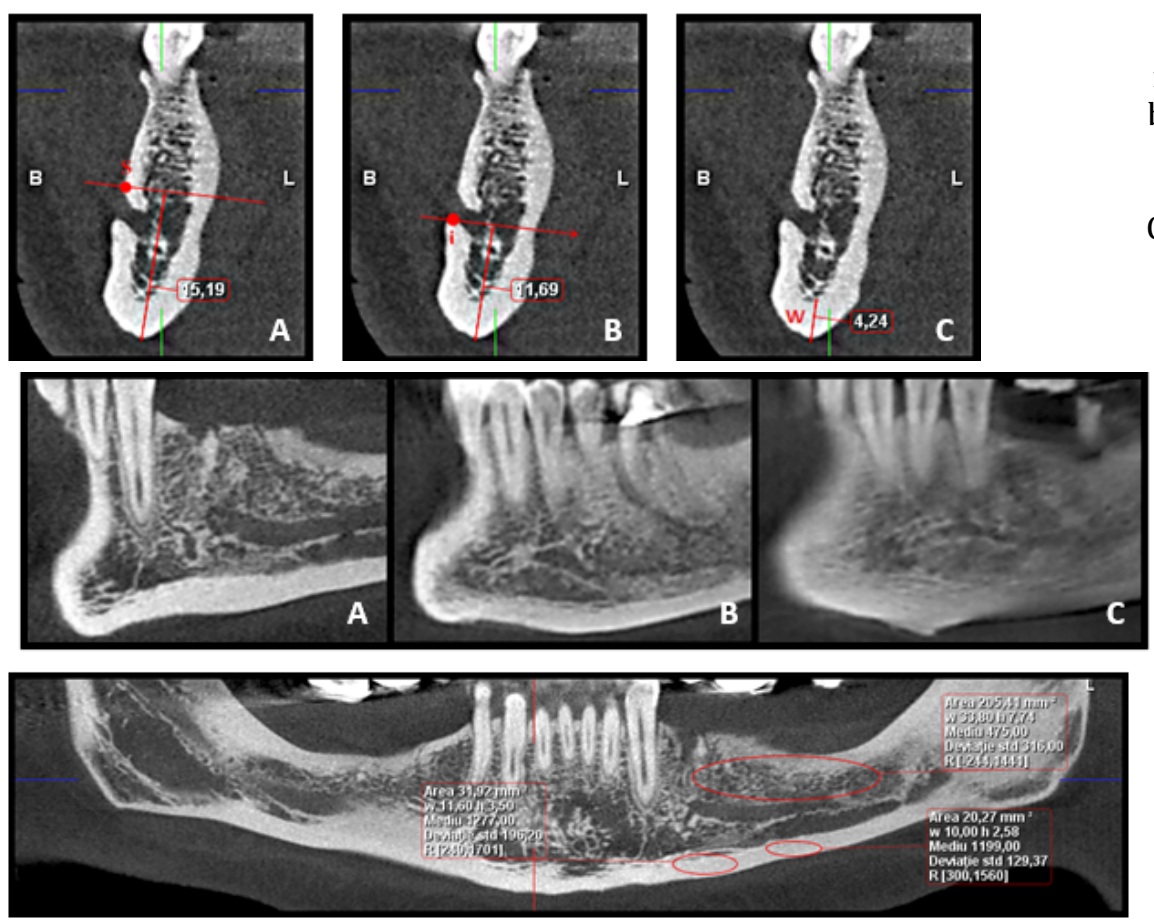

Fig.1. A. Distance from the superior (S) margin of the mental foramen to the inferior border of the mandible. B. Distance from the inferior (I) margin of the mental foramen to the inferior border of the mandible. C. Inferior cortical width (W) of the mandible is measured.

Fig. 2. The types of the inferior mandibular cortex are subjectively classified as follows: A. Type 1: the cortical endosteal margin appears even and regular. B. Type 2: the endosteal margin shows semilunar defects or 1 to 2 layers of cortical endosteal residues. $C$. Type 3: the cortical layer has numerous ( $>3$ ) endosteal residues and is clearly porous.

Fig. 3. Bone mineral density evaluation for cortical and cancellous bone of the mandible for each region of the interest 
were performed by an experienced researcher in oral and maxillofacial radiology with Romexis program 3.0.1 (Planmeca OY, Helsinki, Finland).

\section{Statistical analysis}

Data were analyzed with a statistical software package (SPSS version 20.0, SPSS Inc, Chicago , IL ). Statistical tests were used to measure differences in the quality of mandibular bone, lumbar spine $\left(L_{1}-L_{4}\right)$ and left proximal femur BMD between T,DM and T,DM groups.

The relationships between the $\mathrm{CBCTI}(\mathrm{S}), \mathrm{CBCTI}(\mathrm{I})$, CBCTCMI, and BMDs were assessed using a t-test. The CTMI was determined by linear regression analysis.

\section{Results and discussions}

The osteoporotic and diabetic groups did not differ significantly in regard to age, weight, height, years since diabetes onset and endetulous region of the mandible. Clinical characteristics of all patients are presente in Table 1. Following the evaluation of skeletal status in the lumbar spine $\left(L_{1}-L_{4}\right)$ and proximal left femur, osteoporotic and diabetic patients were distributed as can be seen in Table 2.

The evaluation of BMD values based on the diabetes mellitus type indicated significantly lower BMD values at the lumbar spine $(t=9.815, p=0.003326)$ in patients with type 1 diabetes (Table 3). The BMD mean values of the proximal left femur for the osteoporotic, type 1 and 2 diabetic groups are presented in Table 4. There was statistically significant difference between BMD values of the left proximal femur in the type 1 and 2 diabetic groups.

The analysis showed that in type 2 diabetes patients, the cortical bone density values are significantly higher ( $t$ $=4.38, p=0.0430,95 \% \mathrm{Cl}$ ) compared with type 1 diabetes patients but not higher than the osteoporotic group (Table 5). In case of the cancellous bone density, the analysis showed no statistically significant difference between the diabetic groups $(t=3.607, p=0.065,95 \% \mathrm{Cl}$ ) (Table 5). Since the distribution of values is not normal in this case, the results of the analysis took into account the KruskalWallis test, which is specific to these types of data.

Table 1

DISTRIBUTION OF PATIENTS ACCORDING TO CLINICAL CHARACTERISTICS

\begin{tabular}{|c|c|c|c|c|c|}
\hline & \multicolumn{2}{|c|}{ All patients } & $\begin{array}{l}\text { Osteoporosis } \\
\text { group with SR }\end{array}$ & $\begin{array}{c}\text { Type I diabetic group } \\
\text { with } S R\end{array}$ & $\begin{array}{l}\text { Type } 2 \text { diabetic } \\
\text { group with } S R\end{array}$ \\
\hline & \multicolumn{2}{|c|}{$\begin{array}{c}\text { Mean SD } \\
\mathrm{n}=40\end{array}$} & $\begin{array}{c}\text { Mean SD } \\
n=20\end{array}$ & $\begin{array}{c}\text { Mean SD } \\
\mathrm{n}=16\end{array}$ & $\begin{array}{c}\text { Mean SD } \\
\mathrm{n}=24\end{array}$ \\
\hline Age (years) & 45.47 & 10.57 & & & \\
\hline Weight (kg) & 79.75 & 19.94 & & & \\
\hline Height $(\mathrm{cm})$ & 182 & 6.65 & & & \\
\hline YSD (years) & & & & $9.42=4.73$ & $8.33 \pm 2.12$ \\
\hline Anterior Edentulous & \multicolumn{2}{|c|}{$n=19$} & $\mathrm{n}=8$ & $n=3$ & $\mathrm{n}=16$ \\
\hline Posterior edentulous & \multicolumn{2}{|c|}{$\mathrm{n}=21$} & $\mathrm{n}=12$ & $\mathrm{n}=13$ & $\mathrm{n}=8$ \\
\hline
\end{tabular}

*YSD: years since diabetes onset; $S R$ : strontium ranelate.

\begin{tabular}{|c|c|c|c|c|}
\hline Groups & Region & Bone status & Number & \multirow{19}{*}{$\begin{array}{c}\text { Table } 2 \\
\text { DISTRIBUTION OF PATIENTS } \\
\text { ACCORDING TO SKELETAL } \\
\text { STATUS IN PROXIMAL LEFT } \\
\text { FEMUR AND LUMBAR SPINE } \\
\left(\mathrm{L}_{1}-\mathrm{L}_{4}\right)\end{array}$} \\
\hline & & Normal & 19 & \\
\hline & Proximal left femur & Osteopenia & 1 & \\
\hline & & Osteoporosis & 0 & \\
\hline \multirow[t]{3}{*}{$\begin{array}{c}\text { Osteoporosis } \\
\text { patients with SR }\end{array}$} & & Normal & 16 & \\
\hline & $\begin{array}{c}\text { Lumbar spine (L1- } \\
\text { L4) }\end{array}$ & Osteopenia & 4 & \\
\hline & \multirow{4}{*}{ Proximal left femur } & Osteoporosis & 0 & \\
\hline \multirow{6}{*}{$\begin{array}{l}\text { Type 1diabetic } \\
\text { with SR }\end{array}$} & & Normal & 3 & \\
\hline & & Osteopenia & 7 & \\
\hline & & Osteoporosis & 6 & \\
\hline & \multirow{3}{*}{$\begin{array}{l}\text { Lumbar spine (L1- } \\
\text { L4) }\end{array}$} & Normal & 3 & \\
\hline & & Osteopenia & 7 & \\
\hline & & Osteoporosis & 6 & \\
\hline \multirow{6}{*}{$\begin{array}{l}\text { Type } 2 \text { diabetic } \\
\text { with SR }\end{array}$} & \multirow[t]{3}{*}{ Proximal left femur } & Normal & 16 & \\
\hline & & Osteopenia & 8 & \\
\hline & & Osteoporosis & 0 & \\
\hline & \multirow{3}{*}{$\begin{array}{l}\text { Lumbar spine }(\mathrm{L} 1- \\
\mathrm{L} 4)\end{array}$} & Normal & 10 & \\
\hline & & Osteopenia & 14 & \\
\hline & & Osteoporosis & 0 & \\
\hline
\end{tabular}

Table 3

BONE MINERAL DENSITY (BMD) VALUES OF THE OSTEOPOROSIS, TYPE 1 AND 2 DIABETIC GROUPS (LUMBAR SPINE $\mathrm{L}_{1}-\mathrm{L}_{4} \mathrm{~g} / \mathrm{cm}^{2}$ ) WITH STRONTIUM RANELATE TREATMENT.

\begin{tabular}{|l|c|c|c|c|c|}
\hline \multicolumn{1}{|c|}{ Groups } & Mean & Standard deviation & Minimum & Maximum & $t$ \\
\hline Osteoporosis with SR & 0.56 & 0.19 & -1.33 & 1.67 & \\
\hline Type 1 diabetic with SR & -1.10 & 0.14 & -2.8 & 0.89 & 0.99 \\
\hline Type 2 diabetic with SR & 0.15 & 0.13 & -1.11 & 9.81 & 0.003 \\
\hline *SR: strontium ranelate & & & & 0 \\
\hline
\end{tabular}


The analysis of the relationship between lumbar spine BMD and cortical mandibular bone density in patients with diabetes showed a significant correlation $(r=0.63, p$ $<0.01$ ). Also, there is a significant correlation between lumbar spine BMDand cancellous bone density $(r=0.607$, $p<0.01$ ).

If in case of $B M D$ for the lumbar spine $\left(L_{1}-L_{4}\right)$ has been noticed a direct correlation with cortical and cancellous mandibular bone density values, the analysis of the BMD for the proximal left femur showed no significant correlation with cortical and cancellous mandibular bone density values $(r=0.17, p=0.281)$.

All measurements of the CBCT indices were made on both, the left and right side of the mandible. Both the inferior - rightmandibular index $(t=0.0018, p=0.892)$ and inferior - left mandibular index ( $t=0.323, p=0.5729$ ) presents no significant differences of the values in patients with type 1 diabetes compared with those with type 2 diabetes (Table 6). Study of the superior - right and left mandibular index values showed no significant differences by the type of diabetes (Table 6).

Analysis of the right mental index showed significant higher values $(t=6.67, p=0.013)$ in patients with type 2 diabetes compared with type 1 diabetes patients (Table 6). Also, the left mental index values are significantly $(t=$
$6.95, p=0.0121,95 \% C l)$ higher in patients with type 2 diabetes (1.8 $\pm 1.13 \mathrm{SD})$ compared with with type 1 diabetes patients (Table 6).

The study of the association between mandibular cortical index and the type of diabetes mellitus showed the presence of significant correlations (Table 7). T.DM patients presented the highest percent of type 3 mandibular cortical index, while T,DM patients showed the smallest percent $(r=-0.298, \div 2=8.46, p=0.0145,95 \% C l)$.

The analysis of the relationship between lumbar spine $\mathrm{BMD}$ and CBCT indices in patients with diabetes showed a significant correlation (Table 8). CBCTCMI values showed a significant association with the lumbar spine BMD values ( $t=14.93, p=0.00002$ ).

The study demonstrated that none of the CBCT mandibular indices showed no significant correlation with proximal leftfemur BMD, but the right and left mental index showed a significant correlation with the proximal left femur BMD (Table 8).

Diabetes mellitus has been consistently associated with deficient metabolism of the skeletal tissue. Diabetes mellitus and osteoporosis are two frequent medical conditions with an increasing prevalence in the aging population.

Table 4

BONE MINERAL DENSITY (BMD) VALUES OF THE OSTEOPOROSIS, TYPE 1 AND 2 DIABETIC GROUPS (PROXIMAL LEFT FEMUR $\mathrm{g} / \mathrm{cm}^{2}$ ) WITH STRONTIUM RANELATE TREATMENT.

\begin{tabular}{|l|c|c|c|c|c|c|}
\hline Groups & Mean & Standard deviation & Minimum & Maximum & $t$ & $P$ \\
\hline Osteoporosis with SR & 1.89 & 0.23 & -1.90 & 2.90 & & \\
\hline Type 1 diabetic with SR & -1.20 & 0.09 & -2.90 & 0.74 & & \\
\hline Type 2 diabetic with SR & 0.59 & 0.14 & -1.56 & 0.84 & 0.15 & 0.045 \\
\hline *SR: strontium ranelate & & & & & & \\
\hline
\end{tabular}

Table 5

BONE MINERAL DENSITY (BMD) VALUES OF THE OSTEOPOROSIS, TYPE 1 AND 2 DIABETIC GROUPS

(MANDIBLE/HOUNSFIELD UNITS) WITH STRONTIUM RANELATE TREATMENT.

\begin{tabular}{|c|c|c|c|c|c|c|c|}
\hline Groups & & Mean & $\begin{array}{l}\text { Standard } \\
\text { deviation }\end{array}$ & Minimum & Moximum & $t$ & $P$ \\
\hline \multirow{2}{*}{ Osteoporosis with SR } & Cortical bone & 1190 & 239.00 & 890.00 & 1346.00 & 3.20 & 0.045 \\
\hline & Cancellous bone & 980.00 & 210.00 & 490.00 & 1278.00 & 4.10 & 0.067 \\
\hline \multirow[t]{2}{*}{ Type 1 diabetic with SR } & Cortical bone & 704.38 & 352.12 & 234.00 & 1298.00 & 4.38 & 0.043 \\
\hline & Cancellous bone & 562.00 & 329.00 & 209.00 & 1267.00 & 3.60 & 0.065 \\
\hline \multirow[t]{2}{*}{ Type 2 diabetic with SR } & Cortical bone & 896.87 & 230.81 & 569.00 & 1298.00 & 4.38 & 0.043 \\
\hline & Cancellous bone & 739.00 & 259.00 & 430.00 & 1256.00 & 3.60 & 0.065 \\
\hline
\end{tabular}

\begin{tabular}{|l|c|c|c|c|}
\hline CBCT indices & $\begin{array}{c}\text { Osteoporoti group } \\
\text { Mean } \pm S D\end{array}$ & $\begin{array}{c}\text { Type l diabetic group } \\
\text { Mean } \pm \text { SD }\end{array}$ & $\begin{array}{c}\text { Type 2 diabetic group } \\
\text { Mean } \pm \text { SD }\end{array}$ & $\begin{array}{c}\text { Table } 6 \\
\text { MEAN VALUES OF } \\
\text { THE CBCT INDICES IN }\end{array}$ \\
\hline CBCTI(inferior - right side) & $0.56 \pm 0.33$ & $0.45 \pm 0.31$ & $0.44 \pm 0.24$ & OSTEOPOROSIS, \\
CBCTI(inferior - left side) & $0.98 \pm 0.45$ & $0.44 \pm 0.29$ & $0.48 \pm 0.22$ & TYPE 1 AND 2 \\
\hline CBCTI(superior-right side) & $1.23 \pm 0.39$ & $0.50 \pm 0.32$ & $0.57 \pm 0.27$ & DIABETIC GROUPS \\
\hline CBCTI(superior - left side) & $1.73 \pm 0.23$ & $0.53 \pm 0.31$ & $0.59 \pm 0.25$ & WITH STRONTIUM \\
\hline CBCTMI (right side) & $3.59 \pm 1.33$ & $1.67 \pm 1.17$ & $2.47 \pm 0.80$ & RANELATE \\
\hline CBCTMI(left side) & $3.80 \pm 1.13$ & $1.80 \pm 1.13$ & $2.58 \pm 0.75$ & TREATMENT. \\
\hline
\end{tabular}

\begin{tabular}{|l|c|c|c|c|c|c|}
\hline \multirow{2}{*}{ Groups } & \multicolumn{5}{|c|}{ Mandibular cortical index } \\
\cline { 2 - 7 } & \multicolumn{2}{|c|}{ Type I } & \multicolumn{2}{|c|}{ Type 2 } & \multicolumn{2}{c|}{ Type 3 } \\
\hline & $n$ & $\%$ & $n$ & $\%$ & $n$ & $\%$ \\
\hline Osteoporosis & 12 & $59.50 \%$ & 6 & $30.50 \%$ & 2 & $10 \%$ \\
\hline Type 1 diabetic & 6 & $37.50 \%$ & 4 & $25.00 \%$ & 6 & $37.50 \%$ \\
\hline Type 2 diabetic & 9 & $37.50 \%$ & 14 & $58.33 \%$ & 1 & $4.17 \%$ \\
\hline Total & 27 & & 24 & & 9 & \\
\hline
\end{tabular}

Table 7

MANDIBULAR CORTICAL INDEX VALUES OF THE OSTEOPOROSIS, TYPE 1 AND 2 DIABETIC GROUPS WITH STRONTIUM RANELATE TREATMENT. 
Table 8

PEARSON CORRELATION OF CBCT INDICES AND LUMBAR SPINE BONE MINERAL DENSITY AND PROXIMAL LEFT FEMUR

\begin{tabular}{|c|c|c|c|c|}
\hline \multirow[t]{2}{*}{ CBCT indices } & \multicolumn{2}{|c|}{$\begin{array}{c}\text { Pearson correlation of } C B C T \\
\text { indices and lumbar spine } \\
\text { bone mineral density }\end{array}$} & \multicolumn{2}{|c|}{$\begin{array}{l}\text { Pearson correlation of } \\
C B C T \text { indices and and } \\
\text { proximal left femur }\end{array}$} \\
\hline & $(r)$ & $p$ & $(r)$ & $p$ \\
\hline CBCTI(inferior - right side) & 0.5616 & & 0.2343 & 0.146 \\
\hline CBCTI(inferior - left side) & 0.6618 & & 0.2644 & 0.099 \\
\hline CBCTI(superior - right side) & 0.6606 & & 0.2791 & 0.081 \\
\hline CBCTI(superior - left side) & 0.6618 & & 0.2715 & $0.090^{-}$ \\
\hline CBCTMI (right side) & 0.7877 & & 0.3804 & 0.015 \\
\hline CBCTMI(left side) & 0.8051 & 0.000 & 0.3700 & 0.019 \\
\hline
\end{tabular}

There are few studies evaluating the relationship between diabetes and mandibular bone quality [27]. Studies are mostly focused on bone implant problems in diabetic patients [28]. The aim of the present study was to assess the mandibular bone quality in a diabetic patient population, because mandibular bone quality gains special importance in some dental procedures such as osseointegrated implants, grafting or periodontal diseases.

Skeleton bones differ in terms of anatomical structure with a different distribution of trabecular and cortical bone. Trabecular bone has a greater surface area and responds quicker to metabolic changes than cortical bone [29].

The use of CBCT in preoperative bone measurements will help provide the clinician with a prognostic indicator that will provides valuable information about the quality of bone.

Diagnosis of diabetic osteoporosis in the jaws requires the development of a set of value ranges corresponding to the method used. Therefore, the present study provides useful data regarding bone quality in a diabetic study population. This study examined the potential use of the mandibular radiomorphometric indices on CBCT images in diagnosis of osteoporosis in diabetic patients. The results of the present study on the CBCT images showed that the CBCTI(S) and CBCTI (I) was not significantly different between the type 1 and type 2 diabetic groups $(p>0.05)$. On the other hand, the CBCTMI was significantly different between the diabetic groups $(p<0.05)$.

In the present study, DEXA method was used as the gold standard for the BMD measurements in the lumbar and femoral neck. The results showed a lower BMD values at the lumbar spine in type 1 diabetic patients than in type 2 diabetic patients and no significant difference of the BMD values of the left proximal femur between the type 1 and 2 diabetic groups.

Many studies, [30 - 32] have examined the methods for detecting individuals with a low BMD at an early stage. Some investigators have investigated whether panoramic radiographs could play a role in the detection of individuals with osteoporosis [23, 33 - 35]. A basic requirement for this would be that the bone mass in the jaw might be related to that of other skeletal sites in which osteoporosis was a significant problem.

In our study, there appears to be a correlation between mandibular bone density and the BMD of other skeletal sites. Our results on the CBCT images and DEXA investigations showed a significant correlation between mandibular bone density (cortical and cancellous bone) and BMD at the lumbar spine and no significant correlation with BMD for the proximal left femur.
Horner et al. [36] demonstrated that BMD measurements of the mandible showed a significant correlation with those of the lumbar vertebra and femoral neck. Taguchi et al. [31] reported the significant correlations between the mandibular BMD using QCT (quantitative computed tomography) and lumbar and femoral neck BMDs measured by DEXA.

Strontium ranelate is an antiosteoporotic agent that can improve guided bone regeneration [37]. The benefits of strontium ranelate have been reported in different animal models: prevents bone loss using two mechanisms, maintain bone formation at a high level and inhibit bone resorption [38]. These in vivo results are correlated with in vitro data where it is shown that strontium ranelate reduced bone resorption with the help of osteoclasts, and augmented bone formation with the help of osteoblasts [39]. Moreover, strontium ranelate can improve bone biochemical and structural properties [40].

The limitations of this study included the small sample size. Further studies with a larger sample and examination of the relationship between CBCTI in patients with diabetes and BMDs are requested.

\section{Conclusions}

The CBCT technique offer sufficient radiographic information that helps oral surgeons to have a significant role in patient screening and early diagnosis of mandibular osteoporosis.

Also, this study suggests that mandibular bone quality is closely correlated with the skeletal status of the patients with osteoporosis diabetes mellitus who take a treatment with strontium ranelate.

Because the specific causes of low skeletal BMDs in diabetes mellitus are unknown, these patients should be evaluated for known determinants of osteoporosis and offered all appropiate measures to prevent and treat osteoporosis with the ultimate goal of preventing fractures. These data suggest that the antiosteoporotic agent, such as strontium ranelate might have the potential to improve bone structure and the process of bone regeneration as we can observed on the imaging examinations that was used in this study.

\section{References}

1.BOUILLON, R.,Calcified Tissue International.,49,1991; p.155-160. 2.VESTERGAARD, P., Osteoporosis International.,18,2007, p.427-444. 3.J ANGHORBANI, M., VAN DAM, R.M., WILLETT, W.C. \& HU, F.B., American Journal of Epidemiology, 166, 2007, p.495-505.

4.COZEN, L. Does diabetes delay fracture healing? Clinical Orthopaedics and Related Research,82,1972,p:134-140. 
5.SANTANA, R.B., XU, L., BABAKHANLOU, C., AMAR, S., GRAVES, D.T., TRACKMAN, P.C., Diabetes, 52, 2003, p.1502-1510.

6.LOCATTO, M.E., ABRANZON, H., CAFERRA, D., FERNÁNDEZ, M.C., ALLOATTI, R., PUCHE, R.C., Bone Miner., 23, 1993; p.129-144.

7.HOFBAUER, L.C., BRUECK, C.C., SINGH, S.K., DOBNIG, H., J Bone Miner Res., 22, 2007, p.1317-1328.

8.PEDRAZZONI, M., CIOTTI, G., PIOLI, G., GIRASOLE, G., DAVOLI, L., PALUMMERI, E., PASSERI, M., Calcified Tissue International., 45., 1989, p.331-336.

9.KEMINK, S.A., HERMUS, A.R., SWINKELS, L.M., LUTTERMAN, J.A., SMALS, A.G., J ournal of Endocrinological Investigation., 23, 2000, p. 295-303.

10.OLMOS, J..M., PEREZ-CASTRILLON, J.L., GARCIA, M.T., GARRIDO, J.C., AMADO, J.A., GONZALEZ-MACIAS, J., Bone and Mineral., 26, 1994, p.1-8.

11.HEAP, J., MURRAY, M.A., MILLER, S.C., JALILI, T., MOYER-MILEUR, L.J., The J ournal of Pediatrics., 144, 2004; p.56-62.

12.ISAIA, G., BODRATO, L., CARLEVATTO, V., MUSSETTA, M., SALAMANO, G., MOLINATTIN, G.M.., Acta Diabetol Lat., 24, 1987; p.305310.

13.WAKASUGI, M., WAKAO, R., TAWATA, M., GAN, N., KOIZUMI, K., ONAYA, T., Bone 14, 1993, p.29-33.

14.STOLK, R.P., VAN DAELE, P.L., POLS, H.A., BURGER, H., HOFMAN, A., BIRKENHAGER, J.C., ET AL., Bone, 18, 1996, p.545-549.

15.GUIGLIA, R., DI FEDE, O., LO RUSSO, L., SPRINI, D., RINI, G.B., CAMPISI, G., Med Oral Patol Oral Cir Bucal., 18, 2013, p.93-99.

16.DEVLIN, H., KARAYIANNI, K., MITSEA, A., JACOBS, R., LINDH, C., VAN DER STELE, P., ET Al.,Oral Surg Oral Med Oral Pathol Oral Radiol Endod., 104, 2007, p.821-828.

17.GROEN, J.J ., DUYYENSZ, F., HALSTED, J.A., Geront Clin., 2, 1960, p.53-54.

18.AMORIM, M.A., TAKAYAMA, L., JORGETTI, V., PEREIRA, R.M., Osteoporos Int., 17,2006, p.1494-1500.

19.DROZDZOWSKA, B., PLUSKIEWICZ, W., TARNAWSKA, B., Dentomaxillofac Radiol., 31, 2002, p.361-367.

20.BAVA, G., RICCI, G., Stomatologica, 12, 1968, p.105-133.

21.DAGISTAN, S., BILGE, O.M., Dentomaxillofac Radiol., 39, 2010, p.290-294.

22.DEVLIN, H., HORNER, K., Osteoporosis Int.,13, 2002, p.373-378.
23.LEDGERTON, D., HORNER, K., DEVLIN, H., WORTHINGTON, H., Dentomaxillofac Radiol., 28, 1999, p.173-181.

24.J OWITT, N., MAC FARLANE, T., DEVILIN, H., KLEMETTI, E., HORNER, K., Dentomaxillofac Radiol., 28, 1999, p.141 - 144.

25.KLEMETTI, E., KOLMAKOV, S., HEISKANENN, P., VAINIO, P., LASSILA, V., Oral Surg Oral Med Oral Pathol., 75, 1993, p.774-779.

26.KOH, K.J., KIM, K.A., Imaging Sci Dent, 41, 2011, p.101-106.

27.AY, S., GURSOY, U.K., ERSELCAN, T., MARAKOGLU, I., Dentomaxillofac Radiol., 34, 2005, p.327-331.

28.OATES, T.W., HUYNH-BA, G., VARGAS, A., ALEXANDER, P., FEINE, J., Clin Oral Implants Res., 24, 2013, p.117-127.

29.RETZEPI, M., DONOS, N., Clin Oral Implants Res., 21, 2010, p.673681.

30.NACKAERTS, O., JACOBS, R., DEVLIN, H., PAVITT, S., BLEYEN, E., YAN, B., ET AL., Dentomaxillofac Radiol., 37, 2008, p.282-287.

31.TAGUCHI, A., TANIMOTO, K., SUEI, Y., OHAMA, K., WADA, T., Dentomaxillofac Radiol., 25, 1996, p.130-135.

32.GULSAHI, A., PAKSOY, C.S., YAZICIOGLU, N., ARPAK, N., KUCUK, N.O., TERZIOGLU, H., Oral Surg Oral Med Oral Pathol Oral Radiol Endod., 104, 2007, p.692-698.

33.KLEMETTI, E., KOLMAKOV, S., KROGER, H., Scand J Dent Res., 102, 1994, p.68-72.

34.BENSON, B.W., PROHODA, T.J., GLASS, B.J., Oral Surg Oral Med Oral Pathol., 71, 1991, p.349-356.

35.DUTRA, V., DEVLIN, H., SUSIN, C., YANG, J., HORNER, K., FERNANDES, A.R., Oral Surg Oral Med Oral Pathol Oral Radiol Endod., 102, 2006, p.663-668.

36.HORNER, K., DEVILIN, H., Dentomaxillofac Radiol., 27, 1998, p.1721.

37.MAIMOUN, L., BRENNAN, T.C., BADOUD, I., DUBOIS-FERRIERE, V., RIZZOLI, R., AMMANN, P., Bone, 46, 2010, p. 1436.

38.DELANNOY, P., BAZOT, D., MARIE, P.J., Metabolism, 51, 2002, p. 906

39.TAKAHASHI, N., SASAKI, T., TSOUDEROS, Y., SUDA, T., J ournal of Bone and Mineral Research, 18, 2003 p. 1087

40.AMMANN, P., BADOUD, I., BARRAUD, S., DAYER, R., RIZZOLI, R., Journal of Bone and Mineral Research, 22, 2007, p. 1419.

$\overline{\text { Manuscript received: } 20.11 .2019}$ 